\title{
Genetic variation in sperm production
}

\author{
J.J. Ford', S.A. McCoard', T.H. Wise', D.D. Lunstra',3 and G.A. Rohrer'
}

'USDA, ARS, RLH US Meat Animal Research Center, P. O. Box 166; State Spur 18D, Clay Center, NE

68933, 'AgResearch Limited, Grasslands Research Centre, Private Bag 11008 Tennent Drive, Palmerston North, New Zealand, ${ }^{3}$ Retired

In boars, the primary determinant of daily sperm production is the number of Sertoli cells, which establishes testicular weight. The only breed comparison of foetal testicular development in boars contrasted two diverse breeds, White composite (WC, Landrace-Yorkshire) with Meishan, a Chinese breed that undergoes pubertal development at a young age and has small testicular size. During the prenatal period, the pattern of change in testicular development is similar in these two breeds with both having their greatest proportion of proliferating Sertoli cells at 90 days of gestation, and with WC boars possessing more Sertoli cells and greater mass of seminiferous tubules during the latter half of gestation. During the first month of life, Meishan boars accumulate Sertoli cells and mass of seminiferous tubules at a greater rate than WC boars, and Meishan boars undergo terminal differentiation of Sertoli cells at a younger age. Postpubertal boars, within each breed and crossbreds of the two breeds, with small testicular size have increased circulating concentrations of follicle-stimulating hormone. No direct breed comparisons of testicular development are apparent for postpubertal boars of other breeds. Accepting the limitations of data reported from different laboratories, Piau boars reach puberty at an older age and have a greater proportion of their testes occupied with seminiferous tubules than Meishan boars; both breeds have small testes. A gene or genes on the $X$ chromosome code for small testicular size in Meishan crossbred boars; genetic determinants of testicular size and sperm production in other breeds remain to be identified.

\section{Introduction}

Daily sperm production correlates positively with mature testicular size in boars (Fig. 1; Hemsworth et al., 1983; Huang and Johnson, 1996) and with number of Sertoli cells (Orth et al., 1988; Lunstra et al., 2003). Fixed costs associated with collection of semen from boars are high relative to the modest number of doses of sperm per ejaculate. Consequently, technology that identifies boars with larger testes yielding more doses of sperm per collection reduces the cost of swine production for producers who use artificial insemination. Differences in number of sperm per ejaculate can vary by more than three fold among breeds (Kennedy and Wilkins, 1984; Castro et al., 1991; Borg et al., 1993; Colenbrander et al., 1993) with the greatest daily 


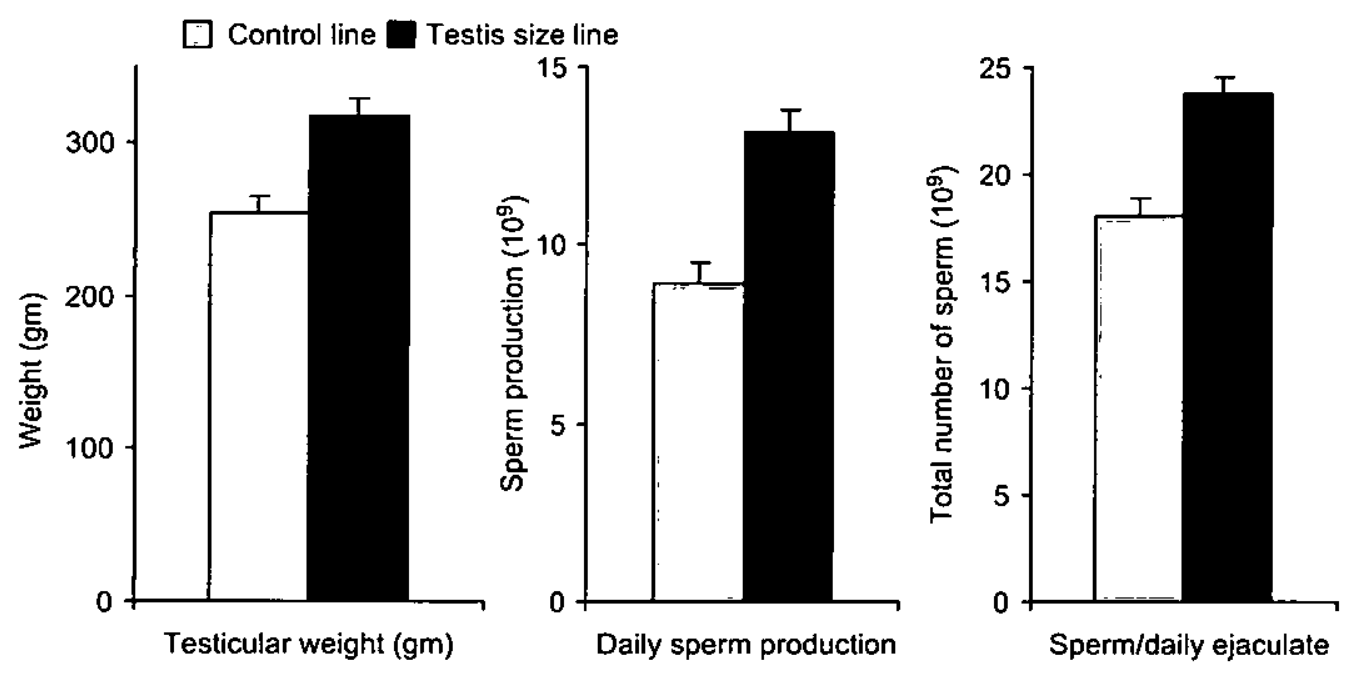

Fig. 1 Sperm production in boars selected for larger testicular size at 150 days of age (n = 24) relative to randomly selected controls ( $n-18$ ), adapted from Huang and Johnson (1996); left panel - parenchyma weight of one testicle at $\sim 13$ months of age; centre panel - daily sperm production for one testicle estimated by determination of homogenisation resistant spermatids; right panel - mean number of sperm per ejaculate during a 3-week period of daily collections just prior to castration.

sperm production in breeds commonly found in intensive swine production. Sperm production improves with age up to two years (Swierstra, 1973; Kennedy and Wilkins, 1984), in response to direct selection for testicular size (Toelle et al., 1984; Johnson et al., 1994) and as a consequence of heterosis (Wilson et al., 1977). However, full understanding of the biological basis for breed differences in sperm production is lacking, although the number of Sertoli cells at completion of puberty is a primary limit. Earlier reviews have summarised endocrine changes associated with testicular development in boars (Colenbrander et al., 1982; Lunstra et al., 1997; Franca et al., 2005). The present assessment of the literature addresses genetic variation in testicular development with emphasis on seminiferous tubules.

\section{Prenatal testicular development}

The rate of development of indifferent porcine gonads has not been scrutinised for breed differences. Genetic sex becomes established at conception; the female phenotype develops unless specific signals induce the male phenotype through a cascade of transcriptional regulators at critical stages (Pailhoux et al., 2001; Cupp and Skinner, 2004; Park and Jameson, 2005). In male pigs, primordial germ cells and a population of somatic cells that contribute to gonadal growth migrate from the primitive gut to the sexually indifferent genital ridge beginning after day 18 of gestation (Takagi et al., 1997; McCoard et al., 2001). By day 23, expression of the sex-determining gene, SRY, in males defines initiation of testis formation (Daneau et al., 1996; Parma et al., 1999), but at day 24 embryonic gonads remain morphologically indifferent (Pelliniemi, 1975). However, at day 26, testicular cords that enclose germ cells and functioning Sertoli cells, indicated by production of anti-Mullerian hormone (AMH), become apparent 
(Pelliniemi, 1976; Tran et al., 1977; McCoard et al., 2001). Peritubular myoid cells enclose these cords leading to seminiferous tubule formation (Pelliniemi, 1976; McCoard et al., 2001).

The only apparent breed comparison pertaining to prenatal testicular development in boars (McCoard et al., 2002b, 2003b) contrasted Landrace-Yorkshire (White composite, WC) with Meishan, a Chinese breed with small testes that reaches puberty at a much younger age than WC boars (Okwun et al., 1996b; Lunstra et al., 1997). Progression of testicular development in these two diverse breeds followed a remarkably similar pattern; $\mathrm{AMH}$ was detected in 40 $50 \%$ of the males within each breed at 26 days of gestation and in $100 \%$ of the boars of both breeds by day 28 . Similarly, 17 alpha-hydroxylase/17, 20-lyase cytochrome P450, an indicator of steroid synthesis in Leydig cells, was observed in - 50\% of boars of each breed at day 28 and in all boars at day 30 of gestation. Between days 30 and 50 of gestation, foetal WC males grew to heavier weights than Meishan males (Hunter et al., 1994; McCoard et al., 2003b), and WC boars had greater testicular weight and mass of seminiferous tubules by 60 days of gestation than did Meishan males (Fig. 2). Tubular mass continued to increase rapidly in both breeds throughout gestation with the final two weeks of gestation characterised by accelerated growth (van Straaten and Wensing, 1977). Number of Sertoli cells was consistently greater in WC than in Meishan foetuses, and the magnitude of this difference was proportional to the difference in mature testicular size of these two very diverse breeds (Okwun et al., 1996b). However, at 90 days of gestation, the largest proportion of Sertoli cells was in a proliferative stage in both breeds, and the number of germ cells did not differ in foetal Meishan and WC boars (McCoard et al., 2003b). The increase in number of germ cells was logarithmic throughout the latter half of gestation as observed previously (van Straaten and Wensing, 1977). Because rate of pubertal development and composition of post-pubertal testes are quite different for Meishan and WC boars, we assume the observed changes in mass of seminiferous tubules and number of Sertoli cells during foetal development relate well to other breeds.

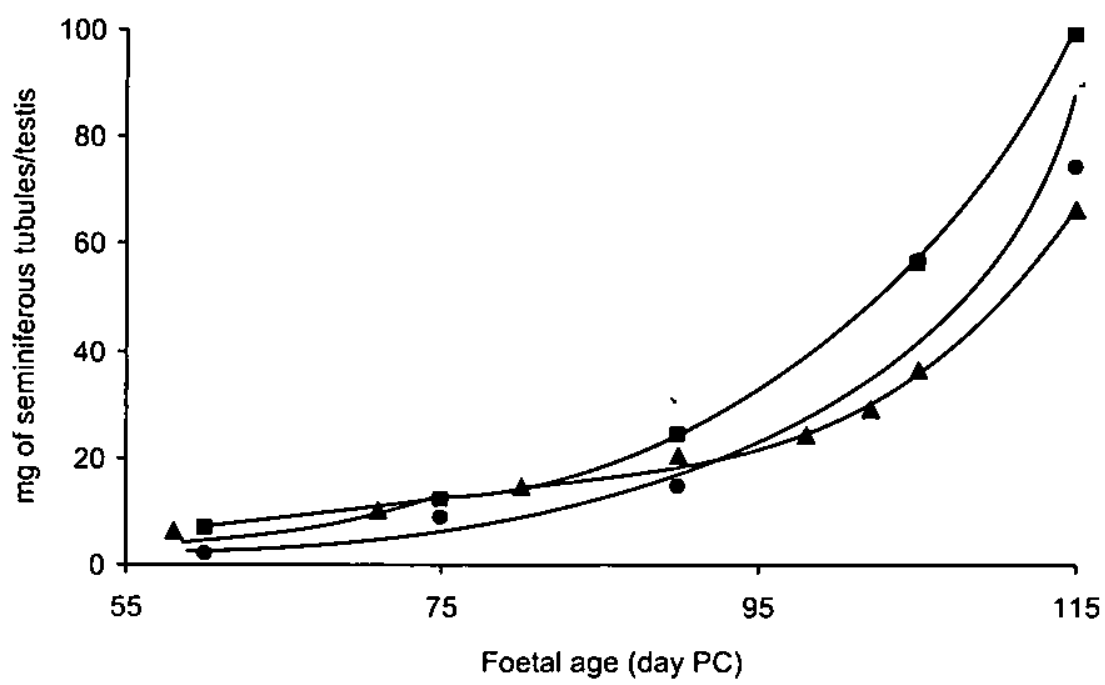

Fig. 2 Estimated weight of the seminiferous tubules within one testicle of foetal boars from three genotypes on specified days postcoitum (PC); day 115 is one-day of age. Data were adapted from McCoard et al., (2003b) for White composite (WC, Landrace x Yorkshire, घ) and Meishan foetuses ( $\bullet$ ) and from van Straaten and Wensing, (1977) for Dutch Landrace $x$ Yorkshire $(L \times Y)$ foetuses ( $(\mathbf{\Delta})$. 


\section{Postnatal testicular development}

Breed differences in postnatal testicular development contrast greatly from the similarity observed in prenatal development of tubular mass. During the first 25 days of postnatal life Meishan boars accumulate Sertoli cells and seminiferous tubules at more rapid rate than WC boars producing greater mass of tubules despite their lower total testicular weight (Fig. 3; McCoard et al., 2003b). Meishan boars retain this advantage in mass of seminiferous tubules over other investigated breeds for their first 100 days of life (Fig. 4). Rapid accrual of tubular mass, expansion of seminiferous tubule diameter and increasing rate of Sertoli cell accumulation define the onset of early male pubertal development in most mammalian species that have been characterised (Sharpe et al., 2003; Franca et al., 2005).

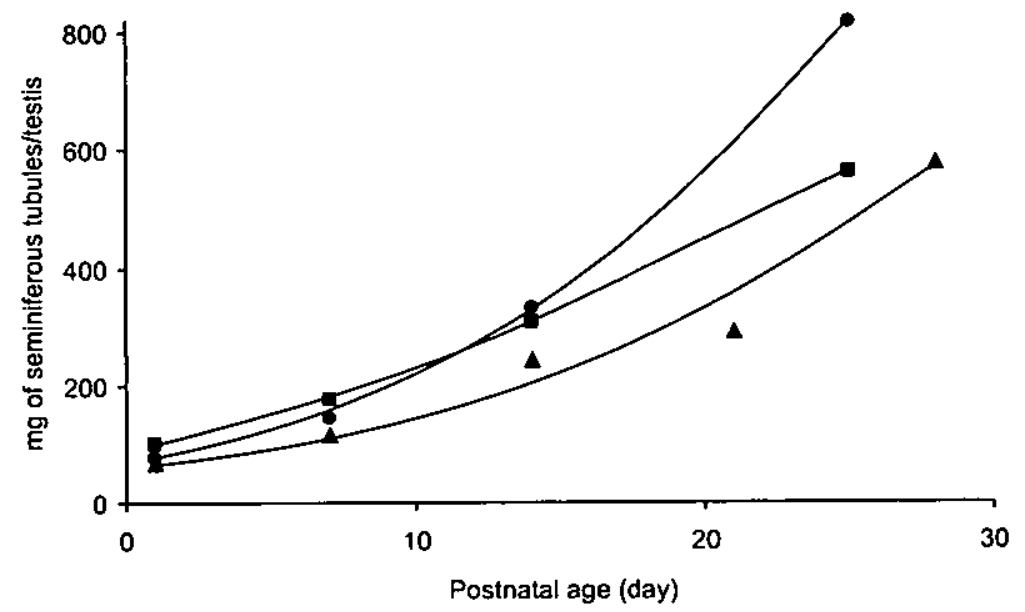

Fig. 3 Estimated weight of the seminiferous tubules within one testicle of boars from three genotypes at specified days of early postnatal age. Data were adapted from McCoard et al., (2003b) for White composite (WC, Landrace $\times$ Yorkshire, $\square$ ) and Meishan boars ( $\bullet$ ) and from van Straaten and Wensing (1977) for Dutch Landrace $x$ Yorkshire $(L \times Y)$ boars $(\mathbf{\Lambda})$.

An accelerated increase in the diameter of seminiferous tubules distinguishes terminal differentiation of Sertoli cells accompanied with increased secretion and accumulation of fluids as the seminiferous tubules become compartmentalised by tight junctions (Russell and Griswold, 1993; van Haaster et al., 1993). This series of changes signals the ensuing formation of the blood-testis barrier and the first appearance of spermatids indicating onset of puberty (Tran et al., 1981). Functional differences exist between foetal and adult Sertoli cells as they undergo transition from a proliferative stage into fully differentiated cells (Migreene et al., 2003; O'Shaughnessy et al., 2003; Sharpe et al., 2003). Meishan boars undergo pubertal development at a young age (Fig. 4) characterised by increased diameter of seminiferous tubules at 30-45 days of age (Harayama et al., 1991; Lunstra et al., 1997) compared to other breeds which exhibit increased diameter of seminiferous tubules after 100 days of age (van Straaten and Wensing, 1977; Allrich et al., 1983; Lee et al., 1987; Kosco et al., 1989; Franca et al., 2000). Meishan and Piau boars attain similar daily sperm production (Table 1) but achieve this through distinctly different patterns of testicular composition and tubular growth. Data relating to testicular weight and composition of present-day boars were not found. The emphasis on selection for leaner carcasses during the past decades potentially produced a delay in pubertal development as earlier pubertal development was associated with an increase in backfat thickness (Johnson et al., 1994). 


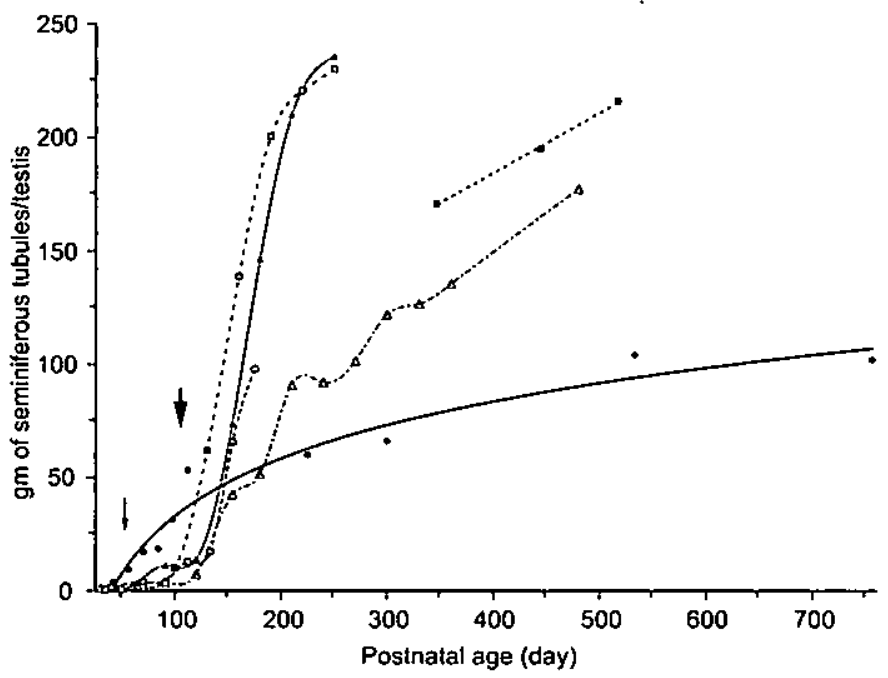

Fig. 4 Estimated weight of the seminiferous tubules within one testicle of boars from six genotypes at specified days of postnatal age. Data were adapted from van Straaten and Wensing (1977) for Dutch Landrace $\times$ Yorkshire ( $L \times Y$, open circles); from Okwun et al., (1996a and 1996b), Lunstra et al., (1997) and D.D. Lunstra, unpublished, for Meishan (closed circles); from Okwun et al., (1996a and 1996b), Lunstra et al., (1997) and D.D. Lunstra, unpublished for 4-breed White composite (WC, closed squares); from Allrich et al., (1983) for Landrace $\times$ Duroc ( $L \times D$, open squares); from Castro et al., (1991) and Franca et al., (2000) for Piau (open triangles) and from Lee el al., (1987) for Hampshire $\times$ Duroc $\times$ Yorkshire ( $H \times D \times Y$, closed triangles). Small arrow indicates approximate timing of rapid expansion of diameter of seminiferous tubules of Meishan boars, and the large arrow approximates initiation of rapid expansion of diameter of seminiferous tubules in boars of the other five genotypes.

Table 1. Breed differences in testicular composition and sperm production of one testicle

\begin{tabular}{|c|c|c|c|c|c|c|}
\hline Breed & $N$ & Age (d) & $\begin{array}{c}\text { Testicular wt } \\
(\mathrm{gm})^{\mathrm{s}}\end{array}$ & $\begin{array}{c}\text { Proportion of } \\
\text { tubles }\end{array}$ & $\operatorname{TDSP}\left(10^{9}\right)^{6}$ & $\begin{array}{c}\text { Sperm/day/ } \\
\text { gm tubule }\left(10^{6}\right)\end{array}$ \\
\hline White Composite' & 5 & 346 & 271 & 0.69 & 6.0 & 35.1 \\
\hline White Composite ${ }^{2}$ & 13 & 464 & 274 & 0.73 & 5.5 & 29.6 \\
\hline Meishan' & 5 & 225 & 135 & 0.49 & 2.5 & 41.5 \\
\hline Meishan ${ }^{2}$ & 23 & 525 & 153 & 0.57 & 2.8 & 34.4 \\
\hline West African' & 5 & 332 & 74 & 0.60 & 1.4 & 35.6 \\
\hline $\mathrm{Piau}^{3}$ & 12 & 332 & 159 & 0.79 & 2.9 & 24.2 \\
\hline $\mathrm{Piau}^{3}$ & 3 & 480 & 219 & 0.81 & - & - \\
\hline $\begin{array}{c}\text { Control-White } \\
\text { Composite }\end{array}$ & 18 & 389 & 286 & 0.71 & 8.9 & 49.1 \\
\hline $\begin{array}{c}\text { Select-White } \\
\text { Composite }\end{array}$ & 24 & 409 & 360 & 0.71 & 13.2 & 58.5 \\
\hline
\end{tabular}

'Efficiency of tubules estimated from data of Okwun et al., (1996a, 1996b).

${ }^{2}$ Lunstra et al., (unpublished data adjusted for age within breed; White Composite 297-687 days of age; Meistians 284-889 days of age).

'Efficiency of tubules estimated from data of Castro et al., (1991) using daily sperm production as determined by Franca et al., (2000).

"Efficiency of tubules estimated from data of Huang and fohnson (1996) using volume percent seminiferous tubules determined by Harder et al., (1995).

${ }^{5}$ Single testis.

'Total daily sperm production. 
Differences in testicular composition of post-pubertal boars are apparent among breeds, but such differences have not been assessed to any great extent within a standardised evaluation. The volume percentage of seminiferous tubules in testes of post-pubertal boars generally ranges from $65 \%$ to $75 \%$ in most breeds, but Meishan boars at $55 \%$ and Piau boars at $80 \%$ characterise the reported extremes (Table 1 ).

\section{Genetic determinants of tubular mass}

In mice, only a few genes have a major impact on testicular weight with a heritability of 0.52 (Chubb, 1992; Zidek et al., 1998). A significant proportion of this variation in testicular size was originally attributed to the $Y$ chromosome (Hunt and Mittwoch, 1987); however, more recent studies determined that specific regions of the $X$ chromosome also significantly impact testicular weight in mice (Elliott et al., 2001; Oka et al., 2004). In boars of a Landrace-Large White composite line, direct selection for larger testes at 150 days of age produced a significant increase in mature testicular weight and an increase in total daily sperm production (Fig. 1; Huang and Johnson, 1996). Moreover, this selection advanced pubertal development based on an earlier increase in the volume percentage of seminiferous tubules and an earlier appearance of tubules with a lumen (Harder et al., 1995). This contrasts with the situation in Meishan and Meishan crossbred boars where larger testicular weights align with later onset of pubertal development (Lunstra et al., 1997; Lunstra et al., 2003). Of particular note in boars selected for greater testicular size, the volume percentage of seminiferous tubules in post-pubertal boars was not affected by selection (Harder et al., 1995), documenting that selection in fact increased both the interstitial and the seminiferous tubular components of the testicles.

The striking difference in mass of seminiferous tubules between Meishan and WC boars (Fig. 4) was exploited by establishing a Meishan crossbred population to further investigate the genetic basis for differences in testicular size. The negative relationship of plasma folliclestimulating hormone (FSH) concentrations and testicular size provided the initial impetus for interest in these boars (Ford et al., 1997; Lunstra et al., 1997). In crossbred boars (1/2 Meishan $x 1 / 2$ WC) that were produced by mating $3 / 4$ Meishan $x 1 / 4$ WC sires with $1 / 4$ Meishan $\times 3 / 4$ WC dams and vice versa (Rohrer et al., 2001), it became apparent that post-pubertal plasma FSH concentrations of boars produced by $3 / 4$ Meishan dams were significantly greater than FSH concentrations of boars from $3 / 4$ WC females. Subsequent quantitative trait loci (QTL) analyses determined that testicular size and plasma FSH concentration were associated with a portion of the $X$ chromosome located near the centromere (Rohrer et al., 2001). Post-pubertal boars produced in an ensuing generation confirmed that boars with this region of the $X$ chromosome inherited from the Meishan breed had smaller testes and higher plasma FSH concentrations than boars with this chromosomal region inherited from the WC line (Ford et al., 2001). A subsequent study with Meishan-Duroc crossbred boars castrated at 60 days of age confirmed the QTL for testicular size in this region of the $X$ chromosome (Sato et al., 2003).

In the early studies with Meishan crossbred boars, testicular morphology was evaluated only in boars that represented extremes within the population (Zanella et al., 1999; Lunstra et al., 2003). Boars with high plasma FSH concentrations (the $25 \%$ of the population with the smallest testes) mimicked purebred Meishan boars with their low volume percentage and low mass of seminiferous tubules. Similarly, testicular morphology of boars with low plasma FSH concentrations (the $25 \%$ with the largest testes) approximated that of WC boars with their greater volume percentage and greater mass of seminiferous tubules. Subsequently, this line of boars was maintained for two additional generations followed by conversion to one-quarter Meishan crossbreds and maintenance for an additional three generations of inter se mating. In an evalu- 
ation of all boars ( $1 / 4$ Meishan $\times 3 / 4 \mathrm{WC})$ produced in one farrowing season, testicular weight continued to be $23 \%$ heavier in boars with the WC QTL relative to boars with the Meishan QTL. In contrast to previous evaluations, volume percentage of the seminiferous tubules was similar in both groups (54\%; Ford et al., unpublished data). Testicular composition approximated that found in Meishan boars in spite of the three-quarter WC background that exists within this population. Thus, this portion of the $\mathrm{X}$ chromosome has minimal impact on testicular composition.

Comparative genetic mapping of the porcine $X$ chromosome revealed an order of genes similar, if not identical, to that on the human X chromosome (McCoard et al., 2002a) thereby providing a list of genes as potential candidates to evaluate for polymorphisms that may account for differences in testicular weight (Ross et al., 2005; Harsha et al., 2005). The androgen receptor was an early candidate as its gene resides near the centromere of the $X$ chromosome (Rohrer, 1999), and varying lengths of glutamine and glycine repeats in the open reading frame of androgen receptor are associated with male infertility in humans (Yong et al., 2003; Gottlieb et al., 2005). However, evidence was not found to support variation in the length of these CAG and GGC repeats in the porcine androgen receptor (Song et al., 1999).

The well-characterised extension of Sertoli cell proliferation (i.e., delayed terminal differentiation of these cells) that accompanies hypothyroidism during the early postnatal period in rats and produces larger testes (Hess et al., 1993) directed interest to thyroid-binding globulin (TBG). The gene for this transport protein of thyroxine (T4) resides within the QTL for testicular size in both pigs and mice (McCoard et al., 2002a; Oka et al., 2004). Detection of a polymorphism in the gene for porcine TBG provided an indication that differences in availability of thyroid hormones may regulate testicular size in this species. The Meishan allele codes for a histidine in the binding domain of TBC; whereas the allele that occurs in other investigated breeds of pigs substitutes an alanine for this histidine (Nonneman et al., 2005). This amino acid exchange reduces the binding affinity of TBG for T4 in Meishan pigs relative to the affinity of this protein for $\mathrm{T} 4$ in modern-day breeds. At present, this change is associated with differences in testicular size, but additional studies are required to establish that this allelic change is truly responsible for the observed differences.

A second QTL for testicular size was identified on chromosome 3 in prepubertal MeishanDuroc boars (Sato et al., 2003). This area corresponds closely to QTL for FSH in post-pubertal Meishan-WC boars, but a significant association with testicular weight was not observed in this later study (Rohrer et al., 2001). This may reflect the difference in age at evaluation of testicular weight. At 60 days of age, heavier testicular weights likely relate to earlier terminal differentiation of Sertoli cells and enlargement of the seminiferous tubules in Meishan and Meishan crossbred boars (Lunstra et al.,1997; 2003). Collectively, this series of studies clearly documents that mass of the seminiferous tubules is a heritable trait in boars, and as predicted, greater quantities of seminiferous tubules significantly enhanced sperm production. Correspondingly, sperm production in boars has a moderate heritability (Smital et al., 2005).

\section{Efficiency of sperm production}

The number of germ cells per Sertoli cell is relatively constant within a species (Russell and Peterson, 1984; Orth et al., 1988). However, the study by Huang and Johnson (1996) observed a $26 \%$ increase in mass of seminiferous tubules in boars selected for larger testes which was associated with a $48 \%$ increase in total daily sperm production (Table 1 ). This signifies greater sperm production per unit of tubule $(19 \%)$ and, if number of Sertoli cells per unit of tubule is constant, sperm production per Sertoli cell increased in boars of the select line. Detailed mor- 
phological evaluation of seminiferous tubules in boars from these two lines is required to define composition, but these observations were unexpected due to the assumed constant sperm production per Sertoli cell within a species. Similarly, the initial evaluation of Meishan boars indicated greater production of germ cells per Sertoli cell than observed in WC boars (Okwun et al., 1996a). Further characterisation of Meishan boars based on mass of seminiferous tubules failed to support this difference (Table 1). This issue requires additional investigation as the potential for genetic differences in number of germ cells per Sertoli cell during spermatogenesis would provide a secondary means to improve sperm production of boars.

\section{Endocrine regulation of Sertoli cell proliferation and differentiation}

\section{Follicle-stimulating hormone}

In vitro and in vivo studies with rodents have established the ability of FSH to stimulate proliferation of Sertoli cells during the early postnatal period (Meehan et al., 2000; Allan et al., 2004). In rats, increased proliferation of Sertoli cells with exogenous FSH during early postnatal life produced larger mature testicular size and greater sperm production; however, exogenous FSH treatment was effective only when administered during this specific period (Meachem et al., 1996). Similarly, FSH in vitro stimulated proliferation of porcine Sertoli cells isolated from 21-day-old boars (Goddard et al., 2001), and the neonatal and pubertal increases in plasma FSH in Piau boars correlated with periods of rapid accumulation of Sertoli cells (Franca et al., 2000). On the other hand, accumulation of Sertoli cells in Meishan and Meishan crossbred boars are not tightly coupled with changes in plasma FSH concentrations (Ford et al., 2001; Lunstra et al., 2003; McCoard et al., 2003b). Unilateral castration at 1 and 10 days of age increased FSH secretion, but this produced a very modest $(\sim 16 \%)$ increase in number of Sertoli cells in boars that developed large, hypertrophied testes and no increase in number of Sertoli cells in boars that developed small, hypertrophied testes (Ford et al., 2001; Lunstra et al., 2003). As a result, the sensitive period for stimulation of Sertoli cell proliferation in boars apparently does not occur during early postnatal development, leading to the prediction that the coupling of FSH and Sertoli cell accumulation observed by Franca et al., (2000) may be coincidental rather than a cause and effect relationship.

Exogenous FSH administered to boars from 8 to 40 days of age increased the length of seminiferous tubules at 100 days of age (Swanlund et al., 1995). These investigators predicted increased numbers of Sertoli cells in response to exogenous FSH on the assumption that length of seminiferous tubules was proportional to number of Sertoli cells, but they did not directly determine the number of Sertoli cells. Alternative explanations of their findings are that FSH treatment increased the size of existing Sertoli cells as occurs after unilateral castration of boars (Lunstra et al., 2003) or that the increase in number of Sertoli cells was transient as seemingly occurs after unilateral castration of boars (Putra and Blackshaw, 1985). Moreover, there was no association of neonatal (i.e., before 8 weeks of age) concentrations of plasma FSH with mature testicular size in boars (Ford et al., 2001; McCoard et al., 2003b), and boars that will develop large testes accumulate Sertoli cells as plasma FSH declines from days 10 to 56 of age (Fig. 5; Ford et al., 2001; Lunstra et al., 2003). Therefore, we conclude that endogenous FSH during neonatal and prepubertal development of boars is not limiting (i.e. FSH supports proliferation rather than providing a major stimulus to establish number of Sertoli cells present at adulthood). This conclusion questions the applicability of the rodent model of Sertoli cell proliferation to boars, similar to the concern of extending the rodent model to other mammalian species (Walker, 2003). 


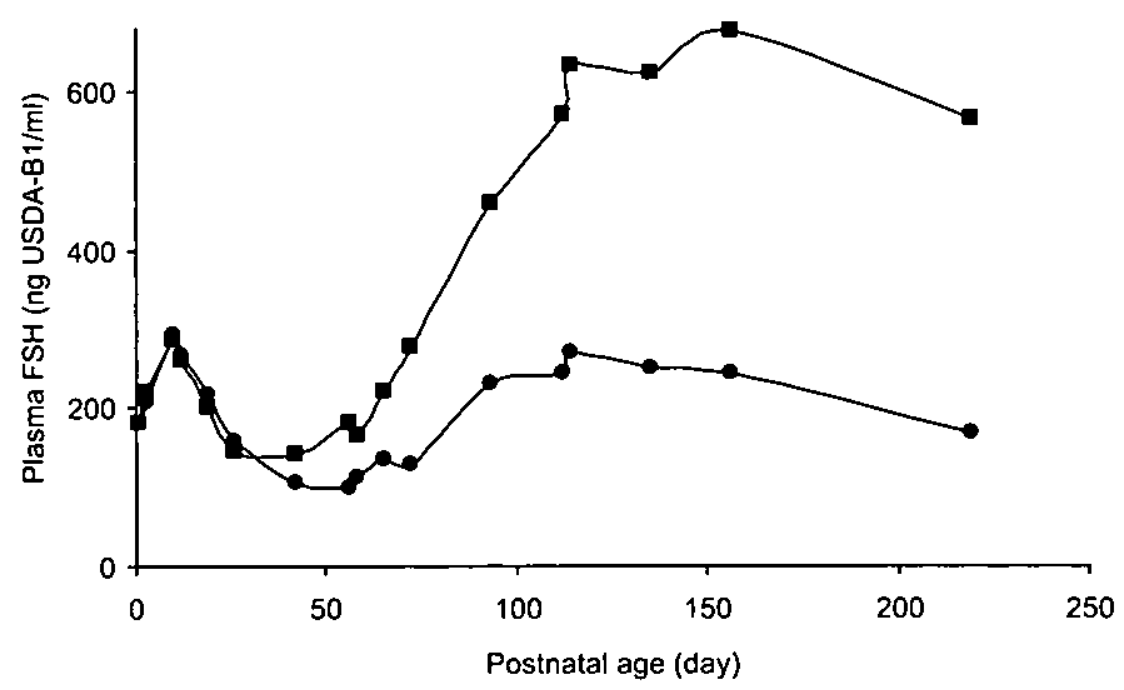

Fig. 5 Plasma concentrations of follicle-stimulating hormone from birth to seven months of age in Meishan (MS $(n-19)) \times$ White composite (WC $(n=18)$ ) boars, adapted from Ford et al., (2001). These boars inherited the testicular size quantitative trait locus of their $X$ chromosome from either the MS or the WC breed.

\section{Thyroid hormones}

Thyroid hormones in rodents have direct effects on Sertoli cell proliferation and differentiation. Induction of hypothyroidism during the early postnatal period of Sertoli cell proliferation extends the duration of this proliferative period (i.e., delays terminal differentiation) resulting in greater testicular size and reduced secretion of FSH in adult males (Kirby et al., 1992; Joyce et al., 1993). Conversely, exogenous tri-iodothyronine (T3) in rats induces cessation of mitogenesis and enlargement of the diameter of seminiferous tubules (Francavilla et al., 1991; van Haaster et al., 1993). However, in boars, hypothyroidism during postnatal development fails to increase mature testicular size (Tran et al., 1998; Klobucar et al., 2003). This, combined with the inability of unilateral castration during early postnatal development to produce an increase in number of Sertoli cells in post-pubertal boars that develop small testes, implicated the prenatal period of testicular development as a critical time for establishing the upper limit for number of Sertoli cells (Lunstra et al., 2003).

Crossbred boars with the Meishan QTL for testicular size undergo earlier terminal differentiation of Sertoli cells as evidenced by an earlier enlargement of the diameter of seminiferous tubules. From 75-105 days of gestation, Meishan male foetuses had greater plasma concentrations of T3 and free T3 than WC boars (MCCoard et al., 2003a). These findings combined with an operative polymorphism in TBG, a gene within the QTL for testis-size on porcine chromosome X (Rohrer et al., 2001; McCoard et al., 2002a; Nonneman et al., 2005), further link thyroid hormones with the regulation of Sertoli cell proliferation. In addition to its role of transporting T3 and T4 in plasma, TBG can undergo proteolytic cleavage that alters availability of thyroid hormones within tissues (Schussler, 2000).

The hypothesis mentioned above requires that prenatal influences of thyroid hormones impact the timing of Sertoli cell differentiation in postnatal boars, a possibility in agreement with 
the inability of unilateral castration during early postnatal development to produce dramatic increases in number of Sertoli cells (Lunstra et al., 2003). However, comparison of thyroid function in Meishan foetuses with that in WC foetuses creates concerns due to differences in body weight and composition of foetuses of these breeds. Thyroid hormones play a critical role in regulating growth, development, differentiation and metabolism of virtually all tissues; thus, inherent metabolic differences between these two diverse breeds should not be ignored as the foundation for the observed differences in plasma $\mathrm{T} 3$ concentrations.

Due to the positive correlation of duration of Sertoli cell proliferation with mature testicular size in boars (Lunstra et al., 2003; McCoard et al., 2003b), greater understanding of factors associated with terminal differentiation of porcine Sertoli cells merits further examination to explain genetic differences in sperm production. In rodents, endocrine factors that induce differentiation of Sertoli cells include increased concentrations of testosterone and T3 (Buzzard et al., 2003; Holsberger et al., 2003; Johnston et al., 2004). Again, this rodent model does not relate well to endocrine changes observed in boars where there is not a consistent association of plasma testosterone and T3 with Sertoli cell accumulation. During the first month of life, testosterone secretion in boars is elevated while Sertoli cells are accumulating rapidly (Franca et al., 2000; Ford et al., 2001; McCoard et al., 2003a). After that, accumulation of Sertoli cells ceases before the pubertal increase of testosterone in boars destined to develop small testes (Meishan QTL for testicular size), but this cessation occurs during the pubertal increase of testosterone in boars that develop large testes (WC QTL for testicular size; Ford et al., 2001). Likewise, evidence for a role of T3 in porcine Sertoli cell differentiation is not overwhelming. Secretion of T3 increases abruptly at birth (Slebodzinski and Brzezinska-Slebodzinska, 1994; McCoard et al., 2003a). Moreover, secretion of thyroid-stimulating hormone increases during prepubertal development of boars (Trudeau et al., 1991), but no associated changes in plasma T3 or T4 concentrations are noted at ages corresponding to termination of Sertoli cell proliferation (Tran et al., 1998; Klobucar et al., 2003). Thus, the rodent model for regulatory roles of testosterone and thyroid hormones in Sertoli cell differentiation does not align well with information available in boars.

Thyroid hormones impact cellular function through a family of thyroid hormone receptors (ThR) encoded by 2 genes, ThRa and ThRb. Both genes can be alternatively spliced giving rise to multiple forms of receptor of which ThRa1, ThRb1 and ThRb2 have been investigated in some detail. ThRa1 is present in Sertoli cells of rodents during neonatal development to provide a means for T3 to impact Sertoli cell proliferation and differentiation Jannini et al., 1994; Arambepola et al., 1998). Neither the mRNA nor the protein for ThRa1 has been evaluated in porcine testes. The role of ThRb1 in testicular development of rats is controversial; its presence was detected in some studies but not in others Jannini et al., 1994; Palmero et al., 1995; Buzzard et al., 2000; Canale et al., 2001). Expression of mRNA for ThRb1 occurs in porcine testes (Palmero et al., 1995), but expression profiles and their relationship to development of seminiferous tubules require greater definition. Immuno-detection of ThRb 1 reveals a similar profile and relative concentrations in Sertoli cells during foetal development of Meishan and WC boars, and relative prenatal concentrations reach a maximum at the time the highest percentage of Sertoli cells are undergoing proliferation (McCoard et al., 2003a). Thus, the pattern of expression of ThRb1, accommodates a role for establishing testicular size in boars if it is the primary mediator of T3 effects on porcine Sertoli cells. Collectively, the current state of knowledge of endocrine changes in boars is inadequate to lead to a convincing hypothesis to explain breed differences in testicular size and sperm production. 


\section{Conclusions}

Developmental patterns of change in the seminiferous tubules of Meishan and WC foetal boars are astonishingly similar in spite of the much earlier age of pubertal development and smaller mature testicular size of Meishan compared with WC boars. Introduction of this diverse breed of pigs from China provided a valuable animal model for investigation of testicular development. Clearly, early cessation of Sertoli cell proliferation accounts for small testicular size in this breed; however, boars of the Piau breed have small testicles, but they achieve this through a longer period of Sertoli cell proliferation and a greater proportion of their testes occupied with seminiferous tubules. Mass of seminiferous tubules in boars is unmistakably a heritable trait and is the primary determinant for daily sperm production. A region on the $q$ arm of the $X$ chromosome contributes to variation in the quantity of seminiferous tubules in Meishan crossbred boars, but studies are required to establish the genetic basis for differences in daily sperm production of other breeds of boars.

\section{References}

Allan CM, Garcia A, Spaliviero J, Zhang FP, Jimenez $M$, Huhtaniemi I and Handelsman D) (2004) Complete Sertoli cell proliferation induced by follicle-stimulating hormone ( $\mathrm{FSH}$ ) independently of luteinizing hormone activity: evidence from genetic models of isolated FSH action Endocrinology $1451587-1593$

Allrich RD, Christenson RK, Ford JJ and Zimmerman DR (1983) Pubertal development of the boar: age related changes in testicular morphology and in vitro production of testosterone and estradiol-17ß Biology of Reproduction 28 902-908

Arambepola NK, Bunick D and Cooke PS (1998) Thyroid hormone and follicle-stimulating hormone regulate Mullerian-inhibiting substance messenger ribonucleic acid expression in cultured neonatal rat Sertoli cells Endocrinology $1394489-4495$

Borg KE, Lunstra DD and Christenson RK (1993) Semen characteristics, testicular size, and reproductive hormone concentrations in mature Duroc, Meishan, Fengjing, and Minzhu boars Biology of Reproduction 49 515-521

Buzzard IJ, Morrison JR, O'Bryan MK, Song $Q$ and Wreford NG (2000) Developmental expression of thyroid hormone receptors in the rat testis Biology of Reproduction 62 664-669.

Buzzard IJ, Wreford NG and Morrison IR (2003) Thyroid hormone, retinoic acid, and testosterone suppress proliferation and induce markers of differentiation in cultured rat Sertoli cells Endocrinology 144 3722-3731

Canale D, Agostini M, Giorgilli G, Caglieresi C, Scartabelli G, Nardini V, Jannini EA, Martino E, Pinchera $A$ and Macchia E (2001) Thyroid hormone receptors in neonatal, pubertal, and adult rat testis Journal of Andrology 22 284-288

Castro ACS, Cardoso FM and Franca LR (1991) Effect of puberty and sexual development on daily sperm production and epididymal sperm reserves of Piau boars Animal Reproduction Science 25 83-90
Chubb C (1992) Genes regulating testis size Biology of Reproduction 42 29-36

Colenbrander B, Feitsma $H$ and Grooten JH (1993) Optimizing semen production for artificial insemination in swine lournal of Reproduction and Fertility Supplement 48 207-215

Colenbrander B, Frankenhuis MT and Wensing CJG (1982) Male sexual development. In Biology of the Domestic Pig pp 3-24 Eds DJA Cole and GR Foxcroft. Butterworth Scientific, Boston

Cupp AS and Skinner MK (2004) Embryonic Sertoli cell differentiation. In Sertoli Cell Biology pp 43-70 Eds MK Skinner and MS Griswold. Elsevier Academic Press, San Diego, CA

Daneau I, Ethier J-F, Lussier JG and Silversides DW (1996) Porcine $S R Y$ gene locus and genital ridge expression Biology of Reproduction $5547-53$

Elliott RW, Miller DR, Pearsall RS, Hohman C, Zhang Y, Poslinski D, Tabaczynski DA and Chapman VM (2001) Genetic analysis of testis weight and fertility in an interspecies hybrid congenic strain for chromosome $X$ Mammalian Genome 12 45-51

Ford J), Wise TH and Lunstra DD (1997) Negative relationship between blood concentrations of folliclestimulating hormone ( $\mathrm{FSH}$ ) and testicular size in mature boars Journal of Animal Science 75 790-795

Ford J, Wise TH, Lunstra DD and Rohrer GA (2001) Interrelationships of porcine $X$ and $Y$ chromosomes with pituitary gonadotropins and testicular size Biology of Reproduction 65 906-912

Franca LR, Avelar GF and Almeida FFL (2005) Spermatogenesis and sperm transit through the epididymis in mammals with emphasis on pigs Theriogenology 63 300-318

Franca LR, Silva VA Jr, Chiarini-Garcia $H$, Garcia SK and Debeljuk L. (2000) Cell proliferation and hormonal changes during postnatal development in the pig Biology of Reproduction 63 1629-1636

Francavilla S, Cordeschi G, Properzi G, Di Cicco L, Jannini 
EA, Palmero S, Fugassa E, Loras B and D'Armieno $M$ (1991) Effect of thyroid hormone on the pre- and post-natal development of the rat testis /ournal of Endocrinology 12935.42

Goddard I, Bauer S, Gougeon A, Lopez F, Giannetti N, Susini $C$, Benahmed $M$ and Krantic $S$ (2001) Somatostatin inhibits stem cell factor messenger RNA expression by Sertoli cells and stem cell factor-induced DNA synthesis in isolated seminiferous tubules Biology of Reproduction 65 1732-1742

Cottlieb B, Lombroso R, Beitel LK and Trifiro MA (2005) Molecular pathology of the androgen receptor in male (in)fertility Reproductive BioMedicine Online $10 \quad 42-48$

Harayama H, Nanjo I, Kanda S and Kato S (1991) Testicular development in Chinese Meishan boars. Theriogenology 36 637.643

Harder RR, Lunstra DD and Johnson RK (1995) Growth of testes and testicular morphology after eight generations of selection for increased predicted weight of testes at 150 days of age in boars Journal of Animal Science $732186-2192$

Harsha HC, Suresh S, Amanchy R, Deshpande N, Shanker K, Yatish AJ, Muthusamy B, Vrushabendra BM, Rashmi BP, Chandrika KN, Padma N, Sharma S, Badano IL, Ramya MA, Shivashankar HN, Peri S, Choudhury DR, Kavitha MP, Saravana R, Niranjan V, Gandhi TK, Ghosh N, Chandran S, Menezes M, Joy M, Mohan SS, Katsanis N, Deshpande KS, Raghothama C, Prasad CK and Pandey A (2005) A manually curated functional annotation of the human $X$ chromosome Nature Cenetics 37 331-332

Hemsworth PH, Winfield CG and Hansen C (1983) High mating frequency for boars: Predicting the effect on sexual behaviour, fertility and fecundity Animal Production 37409.413

Hess RA, Cooke PS, Bunick D and Kirby JD (1993) Adult testicular enlargement induced by neonatal hypothyroidism is accompanied by increased Sertoli and germ cell numbers Endocrinology 132 2607-2613

Holsberger DR, Jirawatnotai S, Kiyokawa $\mathbf{H}$ and Cooke PS (2003) Thyroid hormone regulates the cell cycle inhibitor p27Kip1 in postnatal murine Seroli cells Endocrinology $1443732-3738$

Huang VT and Johnson RK (1996) Effect of selection for size of testes in boars on semen and testis traits fournal of Animal Science $74750-760$

Hunt SE and Mittwoch $U$ (1987) Y-chromosomal and other factors in the development of testis size in mice Cenetic Research, Cambridge 50 205-211

Hunter MC, Faillace LS and Picton HM (1994) Intrauterine and peripheral steroid concentrations and conceptus development in Meishan and Large White hybrid gilts Reproduction, Fertility and Development 6 783-789

Jannini EA, Dolci S, Ulisse S and Nikodem VM (1994) Developmental regulation of the thyroid hormone receptor alpha 1 mRNA expression in the rat testis Molecular Endocrinology 8 89-96

Johnston H, Baker PI, Abel M, Charlton HM, Jackson G, fleming L, Kumar TR and O'Shaughnessy PJ (2004)
Regulation of Sertoli cell number and activity by follicle-stimulating hormone and androgen during postnatal development in the mouse Endocrinology $145 \quad 318-329$

Johnson RK, Eckardt GR, Rathje TA and Drudik DK (1994) Ten generations of selection for predicted weight of testes in swine: Direct response and correlated response in body weight, backfat, age at puberty, and ovulation rate fournal of Animal Science 72 1978-1988

Joyce KL, Porcelli J and Cooke PS (1993) Neonatal goitrogen treatment increases adult testis-size and sperm production in the mouse fournal of Andrology 14 $448-455$

Kennedy BW and Wilkins IN (1984) Boar, breed and environmental factors influencing semen characteristics of boars used in artificial insemination Canadian Journal of Animal Science 64 833-843

Kirby JD, Jetton AE, Cooke PS, Hess RA, Bunick D, Ackland JF, Turek FW and Schwartz NB (1992) Developmental hormonal profiles accompanying the neonatal hypothyroidism-induced increase in adult testicular size and sperm production in the rat Endocrinology 131 559-565

Klobucar I, Kosec M, Cebulj-Kadunc $\mathbf{N}$ and Majdic $\mathbf{G}$ (2003) Posinatal hypothyroidism does not affect prepubertal testis development in boars Reproduction of Domestic Animals 38 193-198

Kosco MS, Loseth KJ and Crabo BG (1989) Development of the seminiferous tubules after neonatal hemicastration in the boar fournal of Reproduction and Fertility 871.11

Lee K-H, Diekman MA, Moss GE and Allrich RD (1987) Pituitary gonadotropins, hypothalamic gonadotropinreleasing hormone, and testicular traits of boars exposed to natural or supplemental lighting during pubertal development Biology of Reproduction 36 1164-1169

Lunstra DD, Ford J], Klindt J and Wise TH (1997) Physiology of the Meishan boar. in Control of Pig Reproduction V, Journal of Reproduction and Fertility Supplement 52 181-193 Eds GR Foxcroft, RD Geisert and C Doberska

Lunstra DD, Wise TH and Ford J/ (2003) Sertoli cells in the boar testis: changes during development and compensatory hypertrophy after hemicastration at different ages Biology of Reproduction 68 140-150

McCoard SA, Fahrenkrug SC, Alexander L\}, Freking BA, Rohrer GA, Wise TH and Ford J (2002a) An integrated comparative map of the porcine $X$ chromosome Animal Cenetics 33 178-185

McCoard SA, Wise TH, Fahrenkrug SC and Ford J (2001) Temporal and spatial localization patterns of Gata4 during porcine gonadogenesis Biology of Reproduction 65 366-374

McCoard SA, Wise TH and Ford JJ (2002b) Expression levels of Müllerian-inhibiting substance, GATA4 and 17a-hydrolase/17,20-lyase cytochrome P450 during embryonic gonadal development in two diverse breeds of swine lournal of Endocrinology 175 365374 
McCoard SA, Wise TH and Ford IJ (2003a) Endocrine and molecular influences on testicular development in Meishan and White Composite boars Journal of Endocrinology 178 405-416

McCoard SA, Wise TH, Lunstra DD and Ford JJ (2003b) Stereological evaluation of Sertoli cell ontogeny during foetal and neonatal life in two diverse breeds of swine Journal of Endocrinology 178 395-403

Meachem S\}, McLachlan RI, de Krester DM, Robertson DM and Wreford NG (1996) Neonatal exposure of rats to recombinant follicle stimulating hormone increases adult Sertoli and spermatogenic cell numbers Biology of Reproduction 54 36-44

Meehan T, Schlatt S, O'Bryan MK, de Kretser DM and Loveland KL (2000) Regulation of germ cell and Sertoli cell development by activin, follistatin, and $\mathrm{FSH}$ Developmental Biology 220 225-237

Migrenne SP, Le Racine C, Guillou F and Habert R (2003) Pituitary hormones inhibit the function and differentiation of foetal Sertoli cells Endocrinology 1442617 2622

Nonneman D, Rohrer GA, Wise TH, Lunstra DD and Ford If (2005) A variant of porcine thyroxine-binding globulin has reduced affinity for thyroxine and is associated with testis size Biology of Reproduction 72 214-220

Oka A, Mita A, Sakurai-Yamatani N, Yamamoto H, Takagi N, Takano-Shimizu T, Toshimori K, Moriwaki $K$ and Shiroishi T (2004) Hybrid breakdown caused by substitution of the $X$ chromosome between two mouse subspecies Cenetics 166 913-924

Okwun OE, Igboeli F, Ford IJ, Lunstra DD and Johnson L (1996a) Sertoli cell number and function, spermatogonial number and yield, and daily sperm production in three breeds of boars Journal of Reproduction and Fertility 107 137.149

Okwun OE, Igboeli F, Lunstra, DD, Ford JJ, and Johnson L (1996b) Testicular composition, number of A spermatogonia, germ cell ratios, and number of spermatids in three different breeds of boars fournal of Andrology 107 301-309

Orth JM, Gunsalus GL and Lamperti AA (1988) Evidence from Sertoli cell-depleted rats indicates that spermatid number in adults depends on numbers of Sertoli cells produced during perinatal development Endocrinology 122 787-794

$O^{\prime}$ Shaughnessy PJ, Fleming L, Baker PJ, Jackson $\mathbf{G}$ and Johnston H (2003) Identification of developmentally regulated genes in the somatic cells of the mouse testis using serial analysis of gene expression Biology of Reproduction 69 797-808

Pailhoux E, Mandon-Pepin B and Cotinot C (2001) Mammalian gonadal differentiation: the pig model. In Control of Pig Reproduction VI, Reproduction Supplement 58 65-80 Eds RD Geisert and C Doberska

Palmero S, De Marco P and Fugassa E (1995) Thyroid hormone receptor beta mRNA expression in Sertoli cells isolated from prepubertal testis Journal of MOlecular Endocrinology 14 131-134

Park SY and Jameson JL (2005) Minireview: Transcrip- tional regulation of gonadal development and differentiation Endocrinology 146 1035-1042

Parma P, Pailhoux E and Cotinot C (1999) Reverse transcription-polymerase chain reaction analysis of genes involved in gonadal differentiation in pigs Biology of Reproduction $61741-748$

Pelliniemi LJ (1975) Ultrastructure of the early ovary and testis in pig embryos American Journal of Anatomy 144 89-112

Pelliniemi L) (1976) Ultrastructure of the indifferent gonad in male and female pig embryos Tissue and Cell 8 163-174

Putra DKH and Blackshaw AW (1985) Quantitative studies of compensatory testicular hypertrophy following unilateral castration in the boar Australian fournal of Biological Sciences 38 429-434

Rohrer GA (1999) Androgen receptor (AR) maps to $X p 1.1-q 1.1$ in the porcine genome lournal of Animal Science 77 499-500

Rohrer GA, Wise TH, Lunstra DD and Ford J/ (2001) Identification of genomic regions controlling plasma FSH concentrations in Meishan-White composite boars Physiological Cenomics 6 145-151

Ross MT, Grafham DV, Coffey AJ, Scherer S, McLay K, Muzny D, Platzer M, Howell GR, Burrows C, Bird CP, Frankish A, Lovell FL, Howe KL, Ashurst JL, Fulton RS, Sudbrak R, Wen G, Jones MC, Hurles ME, Andrews TD, Scott CE, Searle S, Ramser J, Whittaker A, Deadman R, Carter NP, Hunt SE, Chen R, Cree A, Gunaratne P, Havlak P, Hodgson A, Metzker ML, Richards S, Scott G, Steffen D, Sodergren E, Wheeler DA, Worley KC, Ainscough R, Ambrose KD, AnsariLari MA, Aradhya S, Ashwell RI, Babbage AK, Bagguley CL, Ballabio A, Banerjee R, Barker GE, Barlow KF, Barrett IP, Bates KN, Beare DM, Beasley H, Beasley O, Beck A, Bethel G, Blechschmidt K, Brady N, BrayAllen S, Bridgeman AM, Brown AJ, Brown MJ, Bonnin D, Bruford EA, Buhay C, Burch P, Burford D, Burgess J, Burrill W, Burton J, Bye JM, Carder C, Carrel L, Chako J, Chapman JC, Chavez D, Chen E, Chen G, Chen Y, Chen Z, Chinault C, Ciccodicola A, Clark SY, Clarke G, Clee CM, Clegg S, Clerc-8lankenburg K, Clifford K, Cobley V, Cole CG, Conquer IS, Corby N, Connor RE, David R, Davies J, Davis C, Davis J, Delgado O, Deshazo D, Dhami P, Ding Y, Dinh H, Dodsworth S, Draper $H$, Dugan-Rocha S, Dunham A, Dunn M, Durbin KJ, Dutta I, Eades T, Ellwood $M$, Emery-Cohen A, Errington $H$, Evans KL, Faulkner L, Francis F, Frankland J, Fraser AE, Galgoczy P, Gilbert J, Gill R, Glockner G, Gregory SG, Gribble S, Griffiths C, Grocock R, Gu Y, Gwilliam R, Hamilton C, Hart EA, Hawes A, Heath PD, Heitmann K, Hennig S, Hernandez J, Hinzmann B, Ho S, Hoffs $M$, Howden PJ, Huckle EJ, Hume J, Hunt PJ, Hunt AR, Isherwood J, Jacob L, Johnson D, Jones S, de Jong PJ, Joseph SS, Keenan S, Kelly S, Kershaw JK, Khan Z, Kioschis P, Klages S, Knights Al, Kosiura A, Kovar-Smith C, Laird GK, Langford C, Lawlor S, Leversha $M$, Lewis $L$, Liu W, Lloyd C, Lloyd DM, Loulseged $H$, Loveland JE, Lovell JD, Lozado R, Lu J, Lyne R, Ma J, Maheshwari 
M, Matthews L.H, McDowall J, McLaren S, McMurray A, Meidl P, Meitinger T, Milne S, Miner G, Mistry SL, Morgan M, Morris S, Muller I, Mullikin JC, Nguyen $N$, Nordsiek G, Nyakatura G, O'Dell CN, Okwuonu G, Palmer S, Pandian R, Parker D, Parrish J, Pasternak S, Patel D, Pearce AV, Pearson DM, Pelan SE, Perez L, Porter KM, Ramsey Y, Reichwald K, Rhodes S, Ridler KA, Schlessinger D, Schueler MG, Sehra HK, ShawSmith C, Shen $H$, Sheridan EM, Shownkeen R, Skuce CD, Smith ML, Sotheran EC, Steingruber HE, Steward CA, Storey R, Swann RM, Swarbreck D, Tabor PE, Taudien S, Taylor T, Teague B, Thomas K, Thorpe A, Timms K, Tracey A, Trevanion S, Tromans AC, d'Urso $M$, Verduzco D, Villasana D, Waldron L, Wall $M$, Wang Q, Warren J, Warry GL, Wei X, West A, Whitehead SL, Whiteley MN, Wilkinson IE, Willey DL, Williams G, Williams L, Williamson A, Williamson $\mathrm{H}$, Wilming L, Woodmansey RL, Wray PW, Yen J, Zhang J, Zhou J, Zoghbi H, Zorilla S, Buck D, Reinhardt R, Poustka A, Rosenthal A, Lehrach $H$, Meindl A, Minx PJ, Hillier LW, Willard HF, Wilson RK, Waterston RH, Rice CM, Vaudin M, Coulson A, Nelson DL, Weinstock G, Sulston JE, Durbin R, Hubbard T, Gibbs RA, Beck S, Rogers I and Bentley DR (2005) The DNA sequence of the human $X$ chromosome Nature 434 325-337

Russell LD and Griswold MD (1993) The Sertoli Cell Cache River Press, Clearwater, Florida

Russell LD and Peterson RN (1984) Determination of the elongated spermatid-Sertoli cell ratio in various mammals lournal of Reproduction and Fertility $\mathbf{7 0}$ 635-641

Sato S, Oyamada Y, Atsuji K, Nade T, Sato S-I, Kobayashi E, Mitsuhashi T, Nirasawa K, Komatsuda A, Saito Y, Terai S, Hayashi T and Sugimoto $Y$ (2003) Quantitative trait loci analysis for growth and carcass traits in a Meishan x Duroc F2 resource population lournal of Animal Science 81 2938-2949

Schussler GC (2000) The thyroxine-binding proteins Thyroid $10 \quad 141-149$

Sharpe RM, McKinnell C, Kivlin C and Fisher IS (2003) Proliferation and functional maturation of Sertoli cells, and their relevance to disorders of testis function in adulthood Reproduction 125 769-784

Slebodzinski AB and Brzezinska-Slebodzinska E (1994) The appearance and activity of tissue $5^{\prime}$. and 5 monodeiodinase during ontogenesis in the foetal pig Journal of Endocrinology 141243.249

Song IH, Rohrer GA, Ford IJ and Wise TH (1999) Androgen receptor: A candidate for a possible QTL on the $X$ chromosome for testicular size and blood FSH levels in boars XVIh Testis Workshop "The Testis: From Stem Cell to Sperm Function" Abstract Il-25, p. 65. (Louisville, KY; April 7-10, 1999)

Smital J, Wolf J and De Sousa LL (2005) Estimation of genetic parameters of semen characteristics and reproductive traits in Al boars Animal Reproduction Science 86 119-130
Swanlund DI, N'Diaye MR, Loseth KJ, Pryor IL and Crabo BG (1995) Diverse testicular responses to exogenous growth hormone and follicle-stimulating hormone in prepubertal boars Biology of Reproduction 53 749-757

Swierstra EE (1973) Influence of breed, age, and ejaculation frequency on boar semen composition Canadian fournal of Animal Science 53 43-53

Takagi Y, Talbot NC, Rexroad CE Jr and Pursel VG (1997) Identification of pig primordial germ cells by immunocytochemistry and lectin binding Molecular Reproduction and Development 46 567-580

Toelle VD, Johnson BH and Robison OW (1984) Genetic parameters for testes traits in swine fournal of Animal Science 59 967-973

Tran D, Meusy-Dessolle $N$ and Josso N (1977) AntiMüllerian hormone is a functional marker of foetal Sertoli cells Nature $269411-412$

Tran D, Meusy-Dessolle $N$ and Josso $N$ (1981) Waning of anti-Mullerian activity: An early sign of Sertoli cell maturation in the developing pig Biology of Reproduction 24 923-931

Tran CY, Rosenkrans CF Jr, Apple JK and Kirby JD (1998) Effect of 6-N-propyl-2-thioracil on growth, hormonal profiles, carcass and reproductive traits of boars Animal Reproduction Science 50 81-94

Trudeau VL, Meijer IC, Vandalem IL and Sanford LM (1991) Plasma thyrotropin concentration in the male pig: Profile from birth to puberty and effect of season and social environment in the young adult Reproduction Nutrition and Development 31 233-240

van Haaster LH, de Jong FH, Docter $R$ and de Rooij DG (1993) High neonatal triiodothyronine levels reduce the period of Sertoli cell proliferation and accelerate tubular lumen formation in the rat testis and increase inhibin levels Endocrinology 133 755-760

van Straaten HWM and Wensing CJC (1977) Histomorphic aspects of testicular morphogenesis in the pig Biology of Reproduction 17 467-472

Walker WH (2003) Molecular mechanisms controlling Sertoli cell proliferation and differentiation Endocrinology 144 3719-3721

Wilson ER, Johnson RK and Wettemann RP (1977) Reproductive and testicular characteristics of purebred and crossbred boars Journal of Animal Science $\mathbf{4 4}$ 939-947

Yong EL, Loy CJ and Sim KS (2003) Androgen receptor gene and male infertility Human Reproduction Update 9 1-7

Zanella E, Lunstra D, Wise T, Kinder J and Ford I (1999) Testicular morphology and function in boars differing in concentrations of plasma follicle-stimulating hormone Biology of Reproduction 60 115-118

Zídek V, Musilová A, Pintír J, Simáková $\mathrm{M}$ and Pravenec $M$ (1998) Genetic dissection of testicular weight in the mouse with BXD recombinant inbred strains Mammalian Genome 9 503-505 